\title{
Low-Dose Radiation Activates Akt and Nrf2 in the Kidney of Diabetic Mice: A Potential Mechanism to Prevent Diabetic Nephropathy
}

\author{
Xiao Xing, ${ }^{1,2}$ Chi Zhang, ${ }^{2,3}$ Minglong Shao, ${ }^{1,2}$ Qingyue Tong, ${ }^{4}$ Guirong Zhang, ${ }^{4}$ Cai Li, ${ }^{5}$ \\ Jie Cheng, ${ }^{5}$ Shunzi Jin, ${ }^{1}$ Jisheng Ma, ${ }^{6}$ Guanjun Wang, ${ }^{5}$ Xiaokun Li, ${ }^{1,2}$ and Lu Cai ${ }^{2,3,7}$ \\ ${ }^{1}$ School of Public Health of Jilin University, Changchun 130021, China \\ ${ }^{2}$ Chinese-American Research Institute for Diabetic Complications, \\ Wenzhou Medical College, Chashan University Park, Wenzhou 325035, China \\ ${ }^{3}$ The Department of Pediatrics, School of Medicine, The University of Louisville, 570 South Preston Street, \\ Baxter I Building Suite 304F, Louisville, KY 40059, USA \\ ${ }^{4}$ Norman Bethune College of Medicine, Jilin University, Changchun 130021, China \\ ${ }^{5}$ Norman Bethune First Hospital, Jilin University, Changchun 130021, China \\ ${ }^{6}$ Engineering Research Center of Bioreactor and Pharmaceutical Development, Jilin Agricultural University, Changchun 130118, China \\ ${ }^{7}$ Departments of Pharmacology and Toxicology and Radiation Oncology, School of Medicine, The University of Louisville, \\ 570 South Preston Street, Baxter I Building Suite 304F, Louisville, KY 40059, USA
}

Correspondence should be addressed to Xiaokun Li, xiaokunli@163.net and Lu Cai, 10cai001@louisville.edu

Received 9 October 2012; Revised 22 October 2012; Accepted 24 October 2012

Academic Editor: Jingbo Pi

Copyright (c) 2012 Xiao Xing et al. This is an open access article distributed under the Creative Commons Attribution License, which permits unrestricted use, distribution, and reproduction in any medium, provided the original work is properly cited.

\begin{abstract}
Repetitive exposure of diabetic mice to low-dose radiation (LDR) at $25 \mathrm{mGy}$ could significantly attenuate diabetes-induced renal inflammation, oxidative damage, remodeling, and dysfunction, for which, however, the underlying mechanism remained unknown. The present study explored the effects of LDR on the expression and function of Akt and Nrf2 in the kidney of diabetic mice. C57BL/6J mice were used to induce type 1 diabetes with multiple low-dose streptozotocin. Diabetic and age-matched control mice were irradiated with whole body X-rays at either single $25 \mathrm{mGy}$ and $75 \mathrm{mGy}$ or accumulated $75 \mathrm{mGy}$ ( 25 mGy daily for 3 days) and then sacrificed at $1-12 \mathrm{~h}$ for examining renal Akt phosphorylation and Nrf2 expression and function. We found that $75 \mathrm{mGy}$ of X-rays can stimulate Akt signaling pathway and upregulate Nrf2 expression and function in diabetic kidneys; single exposure of $25 \mathrm{mGy}$ did not, but three exposures to $25 \mathrm{mGy}$ of X-rays could offer a similar effect as single exposure to $75 \mathrm{mGy}$ on the stimulation of Akt phosphorylation and the upregulation of Nrf2 expression and transcription function. These results suggest that single $75 \mathrm{mGy}$ or multiple $25 \mathrm{mGy}$ of X-rays can stimulate Akt phosphorylation and upregulate Nrf2 expression and function, which may explain the prevention of LDR against the diabetic nephropathy mentioned above.
\end{abstract}

\section{Introduction}

Radiation at high doses is known to cause cytotoxic effects in vitro and in vivo; however, radiation at low doses induces an adaptive effect or hormesis, showing a protective effect on subsequent challenges-induced damage in vitro and in vivo $[1,2]$. One of the major mechanisms for low-dose radiation (LDR) to induce adaptive response is the induction of cellular protective components that offer the protection against the damage induced by subsequent challenges including radiation, chemicals, and even diseases [3].

Diabetes mellitus (DM) is a global health problem due to its serious complications. Among diabetic complications, nephropathy probably is one of the major complications to increase the mortality of diabetic patients or impact their life quality. Although mechanisms by which diabetes induces the development of nephropathy are multiple, excessive production of reactive oxygen species (ROS) diabetic condition seems the primary factor [4-6]. We have phenomenally 
observed the protective effect of LDR on various diabetic complications, including the testicular, renal, and cardiac damages in diabetic rats and mice [7-10]. In fact, an early study from other groups also implicated the protective effect of LDR on brain damage in the diabetic rat model [11]. In order to explore the protective mechanisms by which LDR prevents diabetic complications, we have proposed LDR may stimulate cell survival and growth signaling pathways and up-regulate antioxidant system.

Among cell survival pathways, the protein kinase B (PKB)/Akt, as a family of serine/threonine protein kinases, plays important roles in a diverse numbers of processes including cell survival, cell growth, gene expression, apoptosis, protein synthesis, energy metabolism, and oncogenesis. Several publications have demonstrated the protective role of Akt in preventing the pathogenesis of diabetic nephropathy [12].

Nuclear factor E2-related factor-2 (Nrf2) is a key transcription factor in regulating intracellular redox balance and a sensor of oxidative and electrophilic stress. Nrf2 regulates intracellular antioxidants, phase II detoxifying enzymes, and many other proteins that detoxify xenobiotics and neutralize ROS and/or RNS to maintain cellular redox homeostasis. $\mathrm{NAD}(\mathrm{P}) \mathrm{H}$ quinone oxidoreductase (NQO1), heme oxygenase-1 (HO-1), and glutathione S-transferase are among the well-studied $\mathrm{Nrf} 2$ target genes that are upregulated through the antioxidant response element regulatory element in response to oxidative stress [13-15]. The important role of Nrf2 in combating oxidative stress induced by diabetes has been demonstrated by the increased cardiac and renal sensitivity of $\mathrm{Nrf}_{2}{ }^{--}$mice to diabetes $[13,16,17]$.

The present study, therefore, was to test our hypotheses that LDR protection from diabetes-induced renal damage may include the stimulation of cell survival pathways and the upregulation of antioxidant system. To this end, we have used a type 1 diabetic model that was induced by streptozotocin (STZ) as used before [7-10]. We irradiated these diabetic mice and age-matched controls to different forms of LDR, and then immediately investigate whether LDR can stimulate Akt as a key cell survival pathway and Nrf2 expression and transcription function as the most important antioxidative mechanism. We found that single $25 \mathrm{mGy}$ of X-rays did not, but single $75 \mathrm{mGy}$ or accumulated $75 \mathrm{mGy}$ ( $25 \mathrm{mGy}$ daily $\times 3$ ) of X-rays could significantly stimulate Akt function. These two forms of LDRs also significantly upregulate Nrf2 expression and transcription. The latter was reflected by stimulation of $\mathrm{Nrf2}$ downstream antioxidants including NQO1 and HO-1. Therefore, stimulation of these cell survival pathway and antioxidative mechanisms may play the critical role in the prevention of diabetic renal damage and dysfunction by LDR.

\section{Materials and Methods}

2.1. Animals. Eight weeks old male C57BL/6J mice were purchased from and also housed in Jilin University Animal Center at $22^{\circ} \mathrm{C}$ with a $12: 12$-light-dark cycle and free access to rodent chow and tap water for $\geq 2$ weeks before being used for experiments. All animal procedures were approved by the University Animal Care and Use Committee, which is certified by the Chinese Association of Accreditation of Laboratory Animal Care. Body weights of mice were measured every 3 days.

2.2. Induction of Type 1 Diabetes. Mice were randomly divided into two groups, a STZ-treated diabetic group and age-matched control group. STZ (Sigma Chemical, St. Louis, $\mathrm{MO}$ ) was freshly dissolved in $0.05 \mathrm{M}$ sodium citrate buffer ( $\mathrm{pH}$ 4.5). Both groups of mice were fasted overnight and then were given by intraperitoneal injection of STZ at $60 \mathrm{mg} / \mathrm{kg}$ body weight daily for 6 consecutive days or equivalent volume of the citrate buffer. Blood glucose level was determined using a Freestyle glucometer 1 week after the last injection of STZ. We considered mice to be diabetic when blood glucose was $\geq 12 \mathrm{mmol} / \mathrm{L}$.

2.3. Whole-Body LDR. A Phillips therapeutic X-ray machine (XSS 205FZ) was operated at $200 \mathrm{kV}$ and $10 \mathrm{~mA}$ in the presence of $1.0 \mathrm{~mm} \mathrm{Al}$ and $0.5 \mathrm{~mm} \mathrm{Cu}$ filters. LDR was given to mice in whole body at dose of $25 \mathrm{mGy}$ or $75 \mathrm{mGy}$ with a dose rate of $12.5 \mathrm{mGy} / \mathrm{min}$.

Mice from both diabetic and age-matched control groups were randomly divided into two groups with and without LDR that is, total four groups: control, LDR, DM, and DM/LDR. For LDR groups, mice were further divided into 3 groups: a single dose of $25 \mathrm{mGy}$, a single dose of $75 \mathrm{mGy}$, and accumulated $75 \mathrm{mGy}$ ( $25 \mathrm{mGy}$ daily for 3 days). Eight mice from each group were euthanized at $1,3,6,9$, and $12 \mathrm{~h}$ after LDR exposure. The protocol was approved by the Committee on the Ethics of Animal Experiments of Jilin University, Jilin, China (Permit Number: 2007-0011). All surgery was performed under sodium pentobarbital anesthesia, and all efforts were made to minimize suffering.

2.4. Western Blotting. Tissue lysates were prepared in lysis buffer $(1 \%$ Triton X-100, $150 \mathrm{mmol} / \mathrm{L} \mathrm{NaCl}, 50 \mathrm{mmol} / \mathrm{L}$ Tris, pH 8.0, $1 \mathrm{mmol} / \mathrm{L}$ EDTA, $10 \mathrm{mg} / \mathrm{L}$ phenylmethylsulfonyl fluoride) using a homogenizer on ice. Then supernatants were collected after centrifugation at $12,000 \mathrm{rpm}$ at $4^{\circ} \mathrm{C}$ for $10 \mathrm{~min}$. Protein concentration was determined by the Bradford assay. Equal amount (50 $\mu \mathrm{g}$ protein/lane) of proteins and prestained molecular weight marker (GibcoBRL, Gaithersburg, MD) were loaded onto $12 \%$ SDSpolyacrylamide gels in a minigel apparatus (Mini-Protean II; Bio-Rad). After being separated on an SDS-PAGE gel, proteins were transferred to PVDF membranes $(0.45 \mu \mathrm{m}$ pore size; Millipore). Nonspecific binding to the membrane was blocked for $1 \mathrm{~h}$ at room temperature with $5 \%$ nonfat milk in TBST buffer $(20 \mathrm{mM}$ Tris- $\mathrm{HCl}, 150 \mathrm{mM}$ $\mathrm{NaCl}$, and $0.1 \%$ Tween-20). Membranes were then incubated at $4^{\circ} \mathrm{C}$ with primary antibody in blocking buffer containing 5\% nonfat milk shaking overnight. Primary antibodies used in the present study include antimouse Nrf2 antibody (1:500, Abcam, Cambridge, MA), antimouse NQO1 antibody (1:500, Abcam), antimouse Akt antibody antimouse p-Akt antibody, and antimouse Akt2 antibody 
(1:1000, Cell Signaling Technology, Danvers, MA), and HO-1 antibody (1:100, Santa Cruz, CA). After washing with TBST three times, membranes were incubated with horseradish peroxidase-conjugated secondary antibody for $1 \mathrm{~h}$ (CST 1:2000). The same membrane was probed with $\beta$-actin $(1: 1000)$ as loading control. Blots were developed with enhanced chemiluminescent reagent and target band density was scanned using a Molecular Dynamics 300A Laser Densitometer.

2.5. Immunohistochemical Staining. Sections were blocked with Superblock buffer (Pierce, Rockford, IL) for $30 \mathrm{~min}$. Sections then were incubated with primary antibodies of anti-Akt, anti-phorspho-Akt, anti-Akt2, and anti-Nrf2, as used for Western blotting assays in $1: 50$ dilution overnight at $4^{\circ} \mathrm{C}$. Following washing with PBS for 3 times, these sections were incubated with biotin-labeled secondary antibody at room temperature for $1 \mathrm{~h}$, followed by color development with diaminobenzidine for $2 \mathrm{~min}$.

2.6. Statistical Analysis. Data were collected from repeated experiments and were presented as means $\pm \operatorname{SD}(n=8)$. Comparisons were performed by one-way ANOVA for the different groups, followed by a post hoc Tukey's test for the difference between groups using statistical software SPSS 14.0. Differences were considered to be significant at $P \leq$ 0.05 .

\section{Results}

3.1. Diabetic Animal Model and LDR Effects. Whole-blood glucose levels were similar among experimental groups before induction of diabetes by STZ. One week after the last dose of STZ, whole-blood glucose levels were examined. Once hyperglycemia was diagnosed, diabetic mice and agematched control mice were exposed or shamed to LDR either at single $25 \mathrm{mGy}$, single $75 \mathrm{mGy}$, or accumulated $75 \mathrm{mGy}$ (e.g.: $25 \mathrm{mGy}$ daily for 3 days). Body weights among groups were same before study. STZ-induced diabetes prevented the body-weight gain that occurred in age-matched control group (Figure 1(a)). No effect of LDR on the body-weight gain no matter exposure levels (Figure 1(a)). Figure 1(b) shows that whole-blood glucose levels in the DM group significantly increased and LDR did not affect whole-blood glucose levels either in control or diabetic mice.

\subsection{LDR Increased Renal Akt Function under Diabetic} Conditions. Immunohistochemical staining revealed that the phosphorylated Akt, predominantly localized in the glomerulus of the kidney, was significantly increased at 1,3 and $6 \mathrm{~h}$ after diabetic mice were exposed to $75 \mathrm{mGy}$ of X-rays (Figure 2(a)).

Western blot showed that there was no significant difference for the expression level of renal Akt phosphorylation at Ser 473 ( $p$-Akt) between Control and DM groups. Exposure of control mice to $75 \mathrm{mGy}$ did not significantly increase renal p-Akt level at the times $1-12 \mathrm{~h}$ after irradiation compared to control mice (Figures 2(b), 2(c)).
Compared to control, exposure of diabetic mice to a single 25 mGy LDR did not affect renal $p$-Akt levels; however, exposure to LDR at either a single $75 \mathrm{mGy}$ or an accumulated $75 \mathrm{mGy}(25 \mathrm{mGy} \times 3)$ significantly increased renal p-Akt levels from $1-12 \mathrm{~h}$ with a peak at $6 \mathrm{~h}$ for $75 \mathrm{mGy}$ and from $1-6 \mathrm{~h}$ with a peak at $6 \mathrm{~h}$ for accumulated $75 \mathrm{mGy}$ (Figures 2(b), 2(c)).

3.3. LDR Increased Renal Akt2 Expression under Diabetic Conditions. Immunohistochemical staining revealed that the expression of Akt2, predominantly localized in the glomerulus of the kidney, was significantly increased in DM/LDR group at 3 and $6 \mathrm{~h}$ after irradiation with $75 \mathrm{mGy}$ of X-rays (Figure 3(a)).

Compared to control, exposure of control mice to $75 \mathrm{mGy}$ did not significantly change renal Akt2 expression at any postirradiation time-point. Renal Akt2 expression was significantly decreased in DM group compared with Control, detected by immunohistochemical staining and western blot (Figures 3(a)-3(d)).

Compared to diabetic mice, exposure of diabetic mice to a single $25 \mathrm{mGy}$ LDR also did not affect renal Akt2 expression level (Figure 3(b)); however, exposure to either a single $75 \mathrm{mGy}$ (Figures 3(b), 3(d) or an accumulated $75 \mathrm{mGy}$ $(25 \mathrm{mGy} \times 3$, Figures 3(c), 3(d) significantly increased renal Akt2 levels from 3-9 h with a peak at $6-9 \mathrm{~h}$ for the single $75 \mathrm{mGy}$ and from 3-6h with a peak at $6 \mathrm{~h}$ for the accumulated $75 \mathrm{mGy}$, respectively (Figure 3(d)).

\subsection{LDR Partially Prevented Diabetic Downregulation of} Renal Nrf2 Expression. Immunohistochemical staining revealed that $\mathrm{Nrf2}$ expression, predominantly localized in the glomerulus (Figure 4(a)). The intensity of Nrf2 staining was significantly lower in the kidney of diabetic mice than control or diabetic mice treated with LDR at post $6 \mathrm{~h}$ (Figure 4(a)).

Western blotting showed that the accumulation of Nrf2 was significantly lower in the kidney of diabetic mice than that of corresponding control mice (Figures 4(b), 4(c)). Exposures of diabetic mice to LDR at single $25 \mathrm{mGy}$ did not have any impact on diabetic inhibition of Nrf2 expression; however, exposure to the single $75 \mathrm{mGy}$ significantly prevented diabetic inhibition of the expression of renal $\mathrm{Nrf2}$ in a time-dependent manner from 1 to $6 \mathrm{~h}$ after irradiation (Figures 4(b), 4(c)). Exposure of diabetic mice to the accumulated $75 \mathrm{mGy}(25 \mathrm{mGy} \times 3)$ also significantly prevented the inhibition of renal Nrf2 expression in diabetic kidney at 3 and $6 \mathrm{~h}$ after LDR (Figures 4(b), 4(c)).

3.5. LDR Partially Prevented Diabetic Downregulation of Renal Nrf2 Function. Since Nrf2 is a transcription factor to positively regulate the expression of several downstream genes to play important role in the prevention of oxidative stress and damage, we have examined several of its downstream genes to functionally evaluate Nrf2 in the kidney of diabetic mice with and without LDR. Renal NQO1 expression was found to significantly decrease in diabetic group compared with control, detected by western 

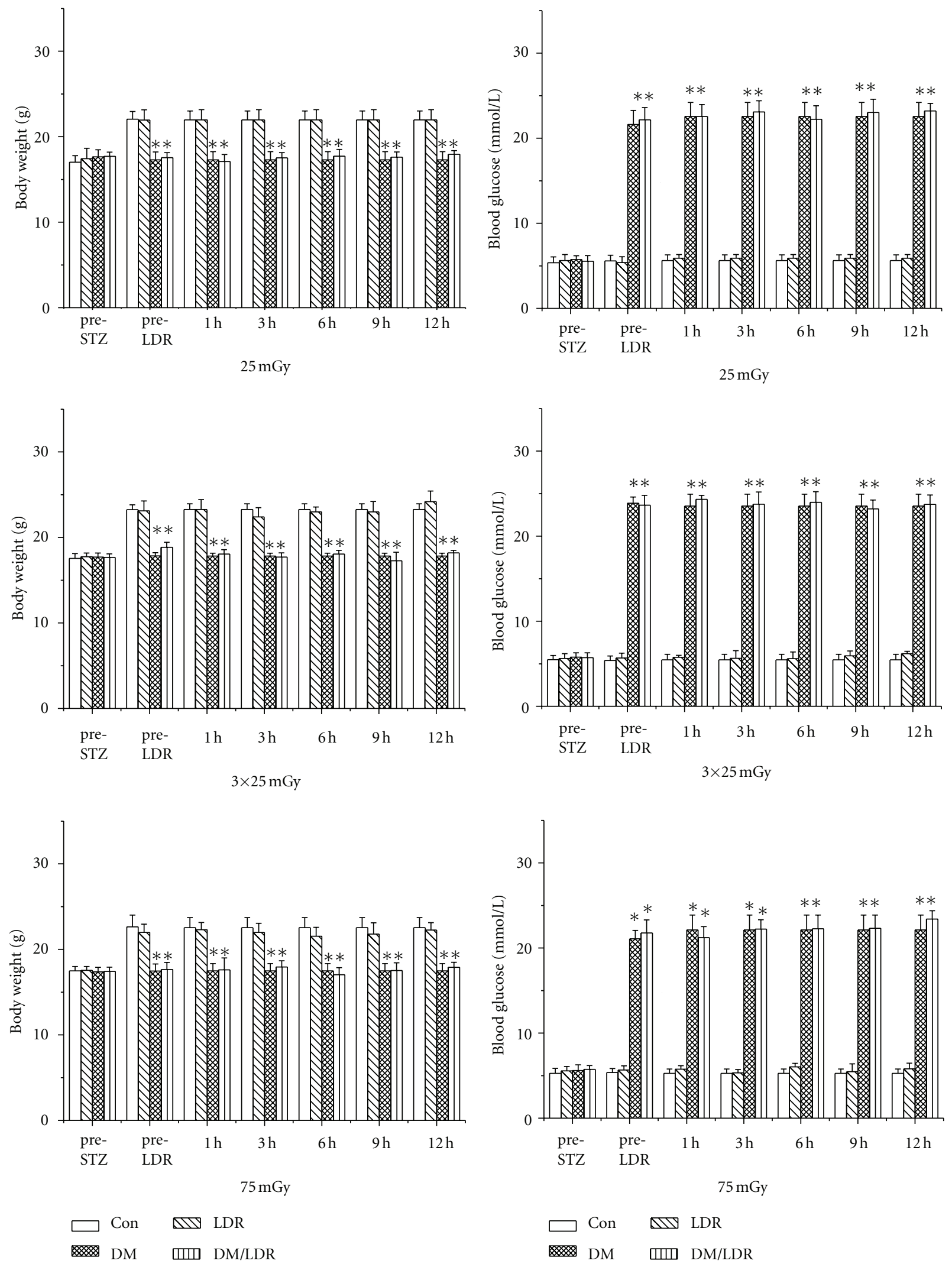

(a)

(b)

FIGURE 1: Effects of LDR on the body weight and blood glucose in diabetic mice. Diabetic and age-matched control mice were irradiated in whole body with LDR $(25 \mathrm{mGy}, 3 \times 25 \mathrm{mGy}$, or $75 \mathrm{mGy})$. Body weights (a) and fasting blood glucose levels (b) were measured before and after diabetes as well as before and after LDR at indicated time points $(n=8)$. Data was presented as mean \pm SD. ${ }^{*} P<0.05$ versus Control. Pre-STZ: before diabetes induction by STZ; Pre-LDR: before diabetic and age-matched control mice were irradiated with LDR. 


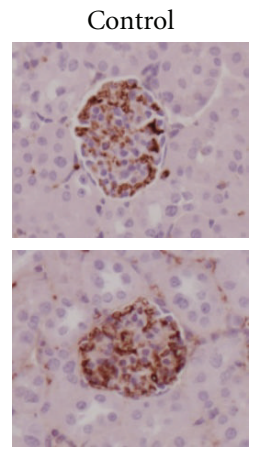

LDR/DM $3 \mathrm{~h}$
$\mathrm{LDR} / 6 \mathrm{~h}$

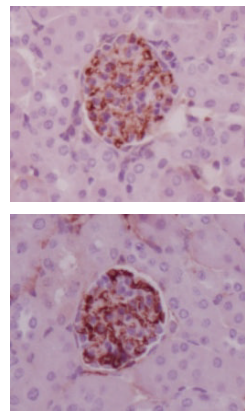

LDR/DM $6 \mathrm{~h}$

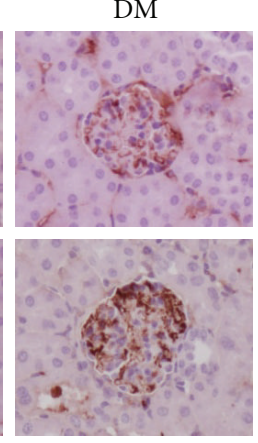

LDR/DM $9 \mathrm{~h}$
LDR/DM $1 \mathrm{~h}$

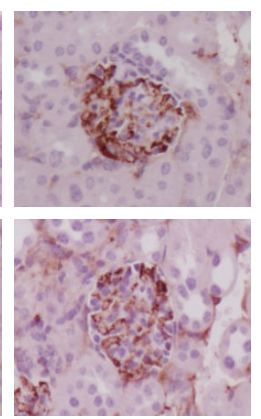

LDR/DM $12 \mathrm{~h}$

(a)

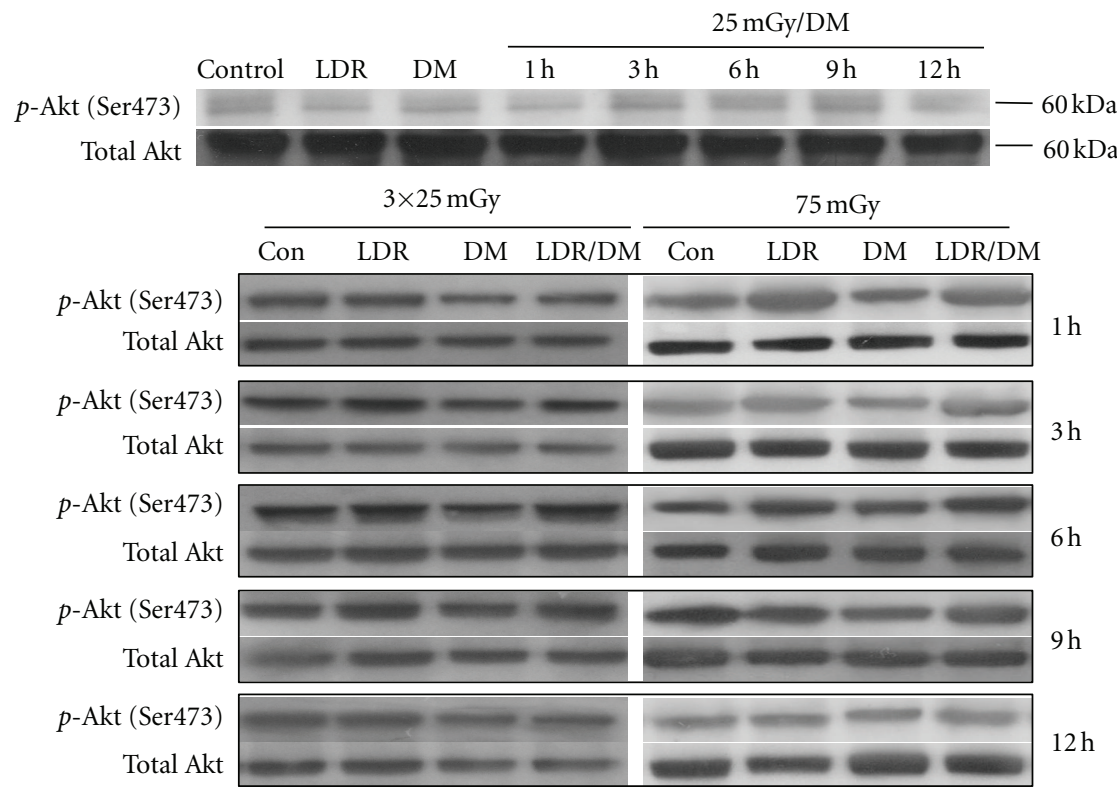

(b)

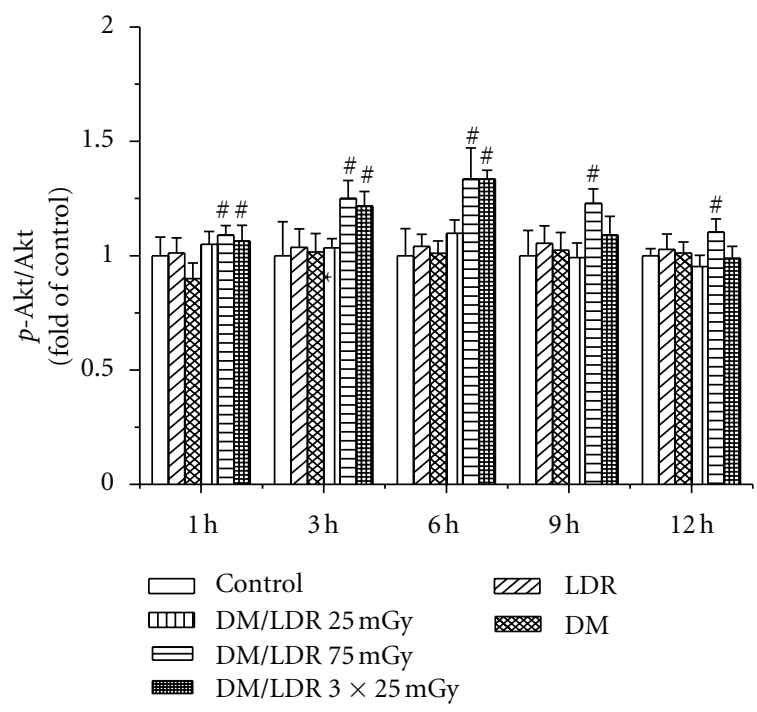

(c)

Figure 2: Effects of LDR on renal Akt function in diabetic mice. Renal tissues from mice exposed to sham, single $25 \mathrm{mGy}, 75 \mathrm{mGy}$ or $3 \times 25 \mathrm{mGy}$ of X-rays were collected at $1,3,6,9$, and $12 \mathrm{~h}$ after LDR to localize the phosphorylated Akt ( $p$-Akt) at Ser473 with immunohistochemical staining ((a), the representative images of the staining were from the group of 75 mGy of LDR). The expression levels of total Akt and $p$-Akt were also examined by western blotting (b), followed by quantitative analysis (c). Data was presented as mean \pm SD. ${ }^{\#} P<0.05$ versus DM. Definition of the abbreviations is provided in Figure 1 legend. 


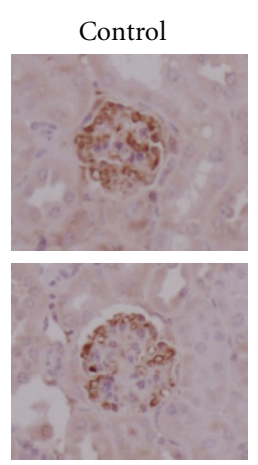

LDR/DM $3 \mathrm{~h}$
$\mathrm{LDR} / 6 \mathrm{~h}$

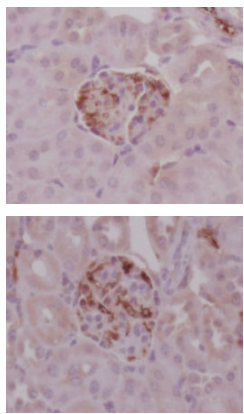

LDR/DM $6 \mathrm{~h}$

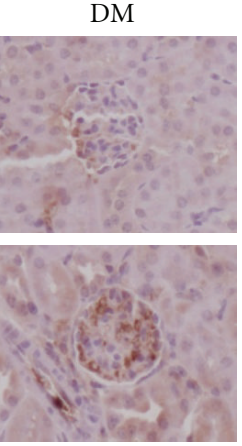

LDR/DM $9 \mathrm{~h}$
LDR/DM $1 \mathrm{~h}$
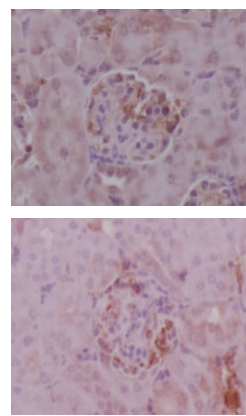

LDR/DM $12 \mathrm{~h}$

(a)

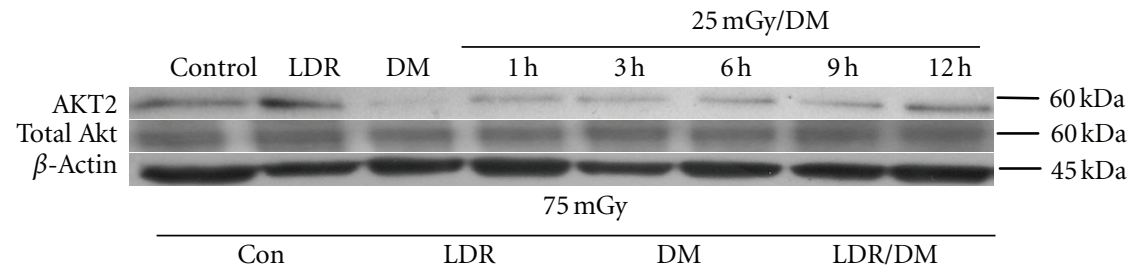

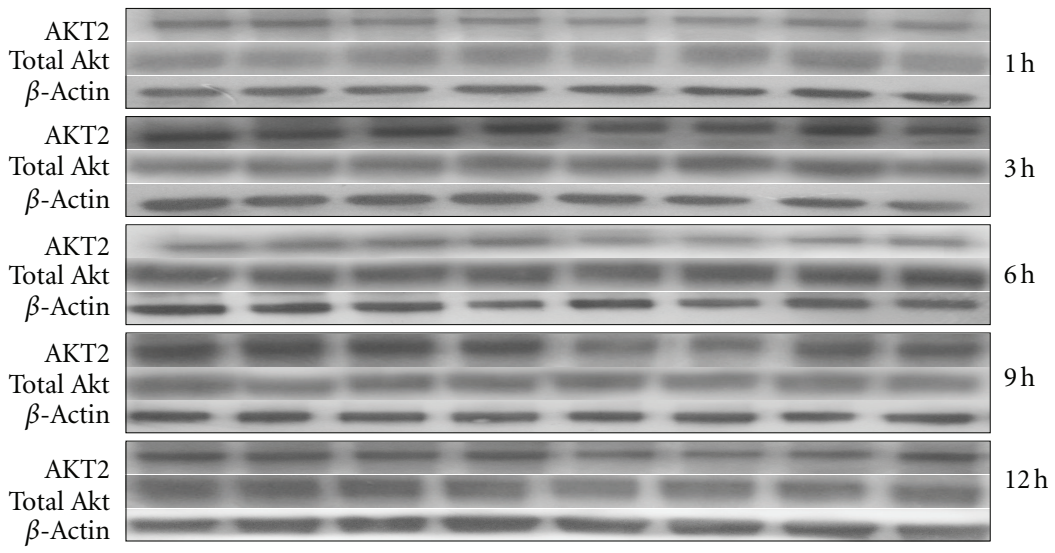

(b)

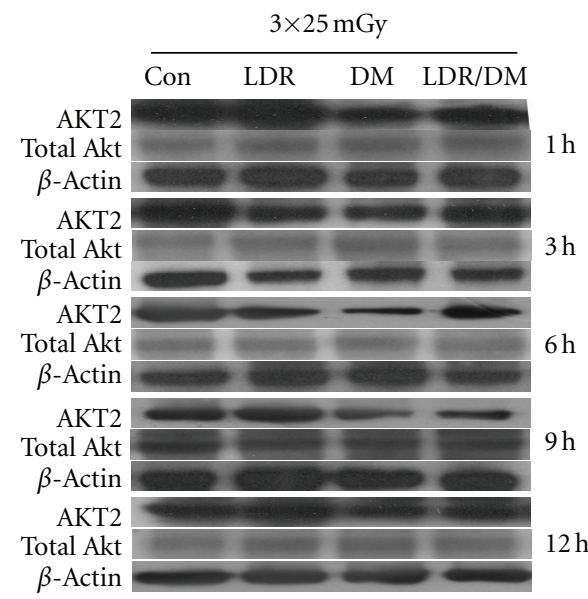

(c)

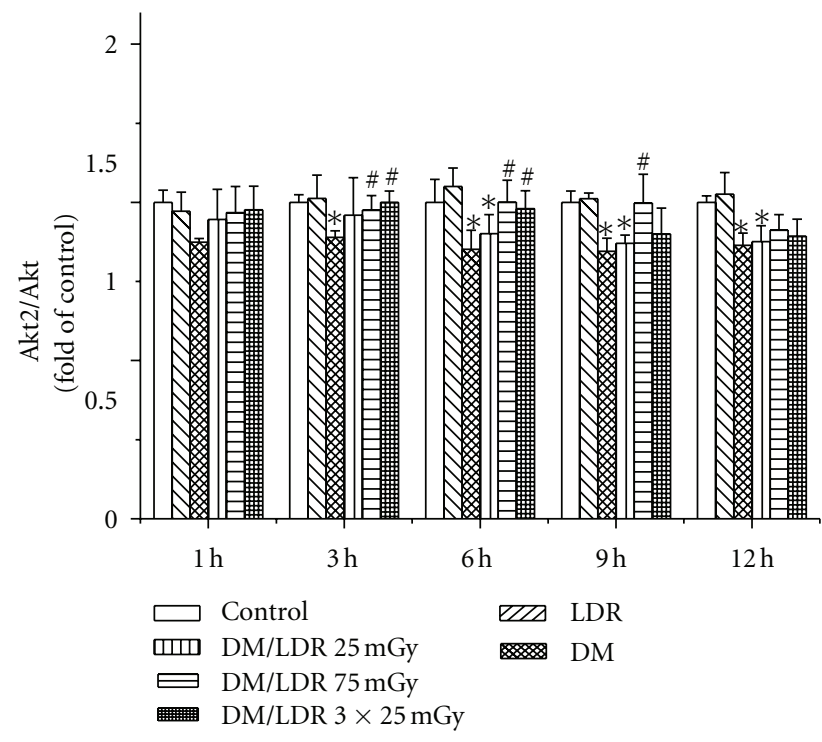

(d)

Figure 3: Effects of LDR on renal Akt2 expression in diabetic mice. Animals were treated and renal tissues were collected as described in Figure 2. The localization of Akt2 expression in the kidney was examined by immunochemical staining (a) and the expression of Akt2 and total Akt were detected by western blotting (b) followed by quantitative analysis (c). Data was presented as mean \pm SD. ${ }^{*} P<0.05$ versus Control, ${ }^{\#} P<0.05$ versus DM. 


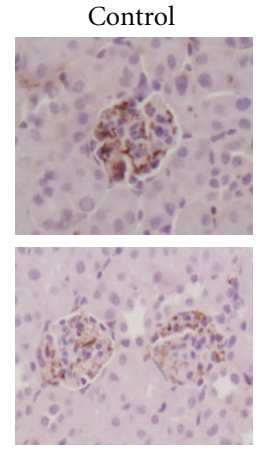

LDR/DM $3 \mathrm{~h}$
$\mathrm{LDR} / 6 \mathrm{~h}$
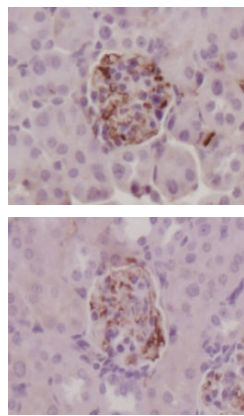

LDR/DM $6 \mathrm{~h}$
$\mathrm{DM}$

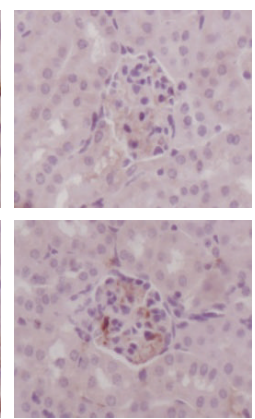

LDR/DM $9 \mathrm{~h}$
LDR/DM $1 \mathrm{~h}$

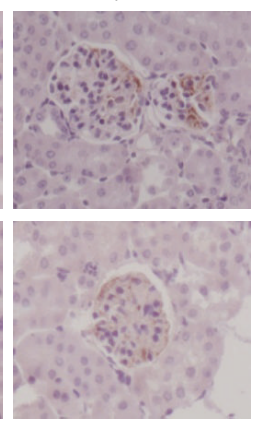

LDR/DM $12 \mathrm{~h}$

(a)

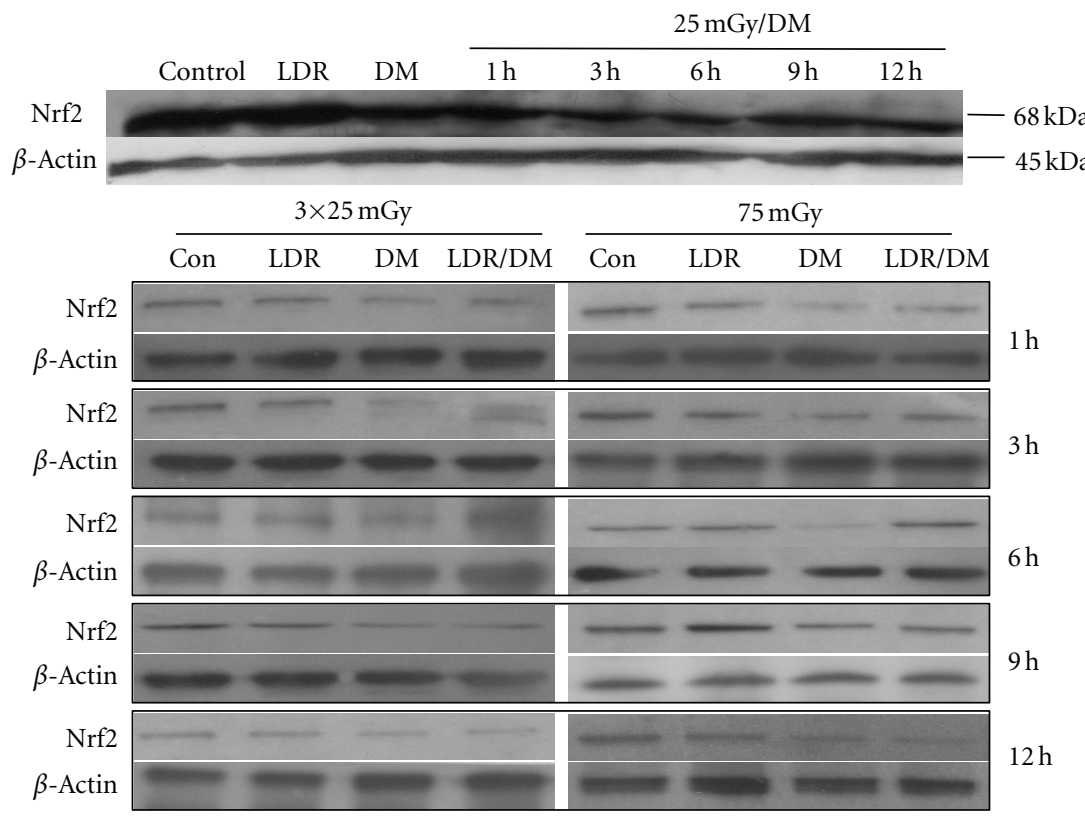

(b)

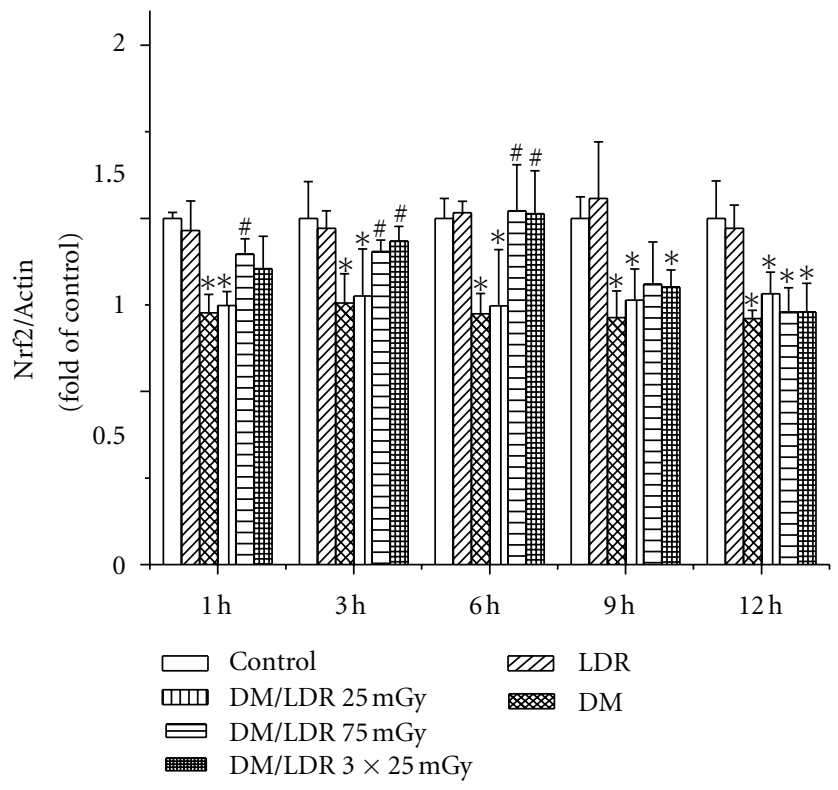

(c)

Figure 4: Effects of LDR on renal Nrf2 expression in diabetic mice. Animals were treated and renal tissues were collected as described in Figure 2. The localization of Nrf2 expression in the kidney was examined by immunochemical staining (a) and the expression of Nrf2 were detected by western blotting (b) followed with quantitative analysis (c). Data was presented as mean \pm SD. ${ }^{*} P<0.05$ versus Control; ${ }^{\#} P<0.05$ versus DM. 


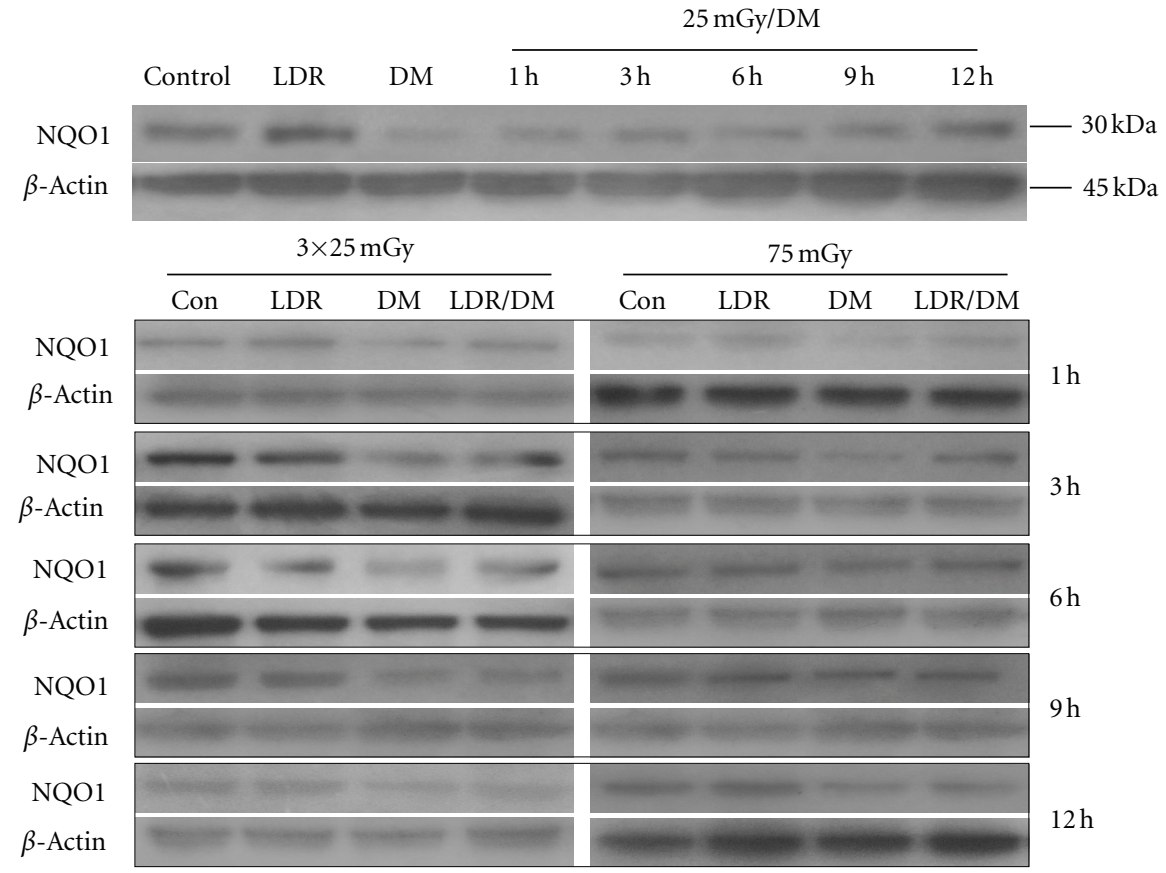

(a)

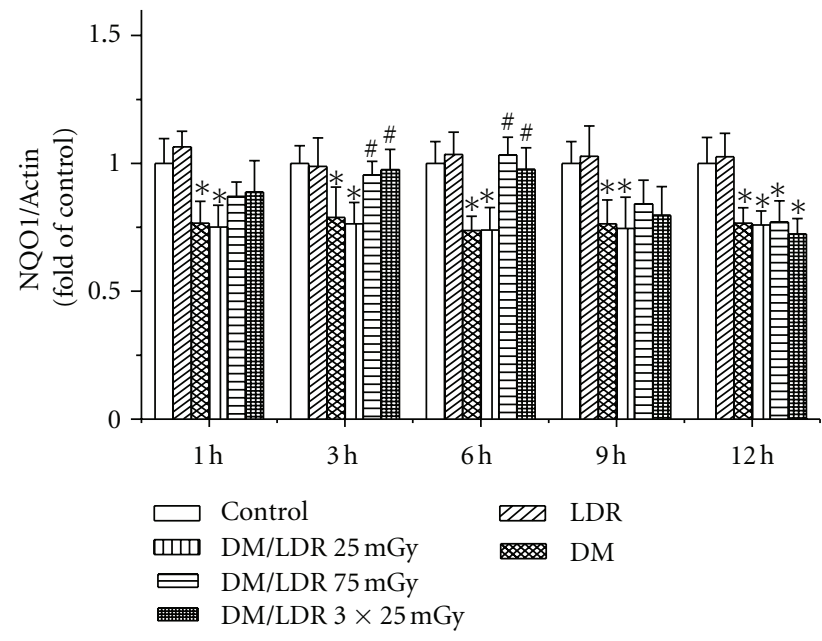

(b)

FIGURE 5: Effects of LDR on renal NQO1 expression in diabetic mice. Animals were treated and renal tissues were collected as described in Figure 2, respectively. The expression of NQO1 was detected by western blotting (b) followed with quantitative analysis (c). ${ }^{*} P<0.05$ versus Control, ${ }^{\#} P<0.05$ versus DM.

blot (Figures 5(a), 5(b)). Exposure of diabetic mice to $25 \mathrm{mGy}$ LDR did not have any effect on renal NQO1 protein expression. However, exposure of diabetic mice to either single $75 \mathrm{mGy}$ or accumulated $75 \mathrm{mGy} \mathrm{X}$-rays significantly prevented diabetic inhibition of renal NQO1 protein expression at 3 and $6 \mathrm{~h}$ after LDR (Figures 5(a), 5(b)).

Renal HO-1 expression, examined by western blot, significantly decreased in DM groups compare to corresponding groups (Figure 6). Exposure of diabetic mice to single $25 \mathrm{mGy} \mathrm{X}$-rays did not have any impact on its expression. In contrast, single $75 \mathrm{mGy}$ or accumulated $75 \mathrm{mGy} \mathrm{X}$-rays can significantly prevent diabetic inhibition of HO-1 expression at 3-9 h after irradiation (Figure 6).

\section{Discussion}

In the present study, we have explored for the first time the effect of LDR on renal expression of Akt as cell survival pathway and Nrf2 as antioxidant transcription regulator in normal and diabetic conditions. We provided the following new findings: $75 \mathrm{mGy}$ of X-rays can stimulate Akt signaling pathway and upregulate Nrf2 expression and function in diabetic kidneys; single exposure of $25 \mathrm{mGy}$ did not, but 


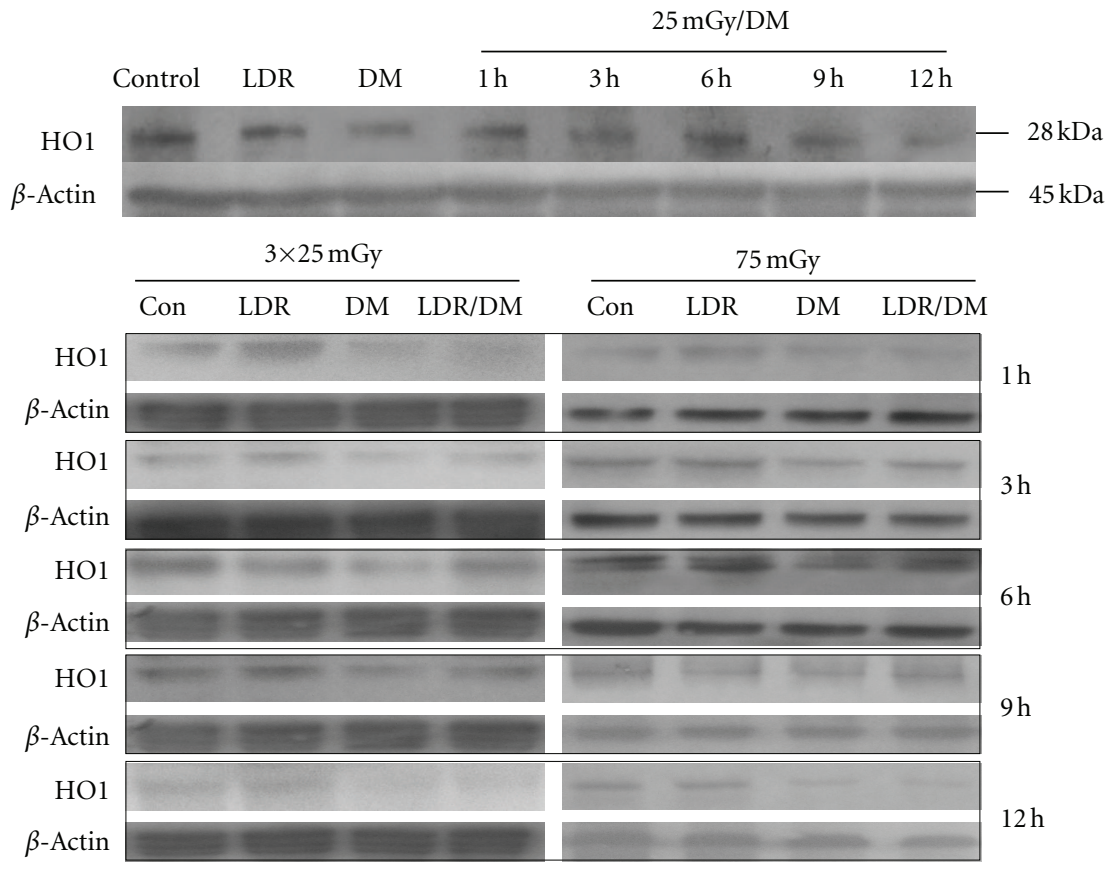

(a)

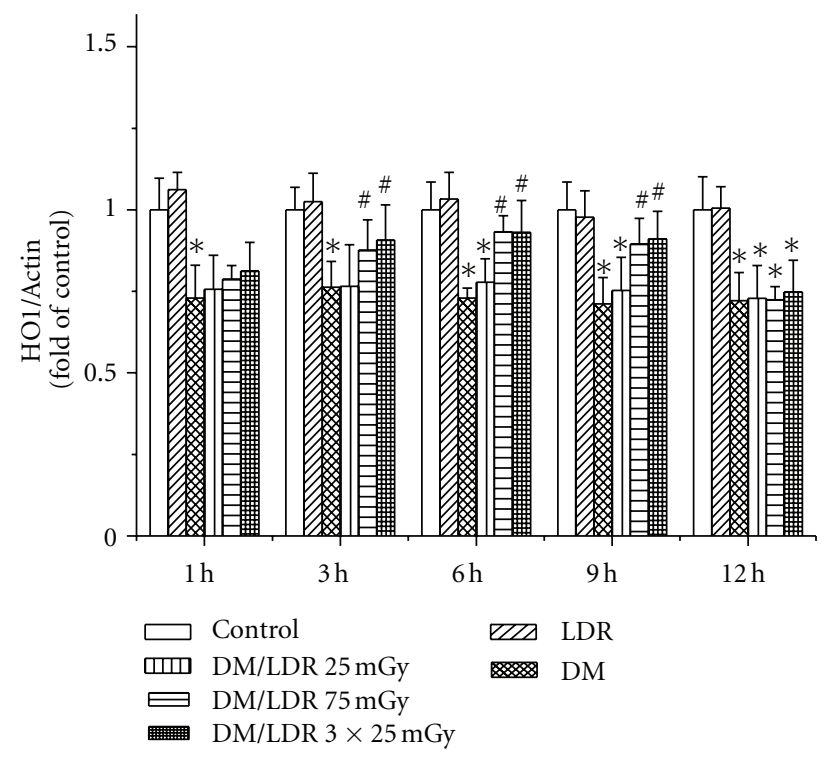

(b)

Figure 6: Effects of LDR on renal HO-1 expression in diabetic mice. Animals were treated and renal tissues were collected as described in Figure 2, respectively. The expression of HO-1 was detected by western blotting (b) followed with quantitative analysis (c). Data was presented as mean $\pm \mathrm{SD} .{ }^{*} P<0.05$ versus Control, ${ }^{\sharp} P<0.05$ versus $\mathrm{DM}$.

three repeated $25 \mathrm{mGy}$ of X-rays could offer similar effects as single $75 \mathrm{mGy}$ exposure on the stimulation of Akt phosphorylation and the upregulation of $\mathrm{Nrf} 2$ expression and function.

In our recent study we have demonstrated that multiple exposures of STZ-induced diabetic mice to $25 \mathrm{mGy}$ of Xrays significantly prevented diabetes-induced renal oxidative damage, inflammation, and fibrosis as well as renal dysfunction [9]. This prompted us to know whether there is a stimulation of either cell survival signaling or antioxidant pathway under diabetic condition by exposure to LDR. In the literature, several studies have used in vitro models to show that LDR was able to stimulate cell survival signaling such as Akt phosphorylation [18, 19]. However, whether LDR can stimulate Akt phosphorylation in the tissue of LDRirradiated animals remain elusive, particularly under diabetic conditions. We found here that single or accumulated $75 \mathrm{mGy}$ of X-rays can significantly stimulate the increase 
of renal Akt phosphorylation at $1-12 \mathrm{~h}$ with a peak at $6 \mathrm{~h}$. We have reported that in the kidney of type 1 diabetic mice induced by STZ as used here, Akt plays an important role in preventing diabetes-induced renal cell death [20]. Similar antiapoptotic effect of Akt on the tissue or in vitro cultured cells in response to various pathogenic stimuli were also extensively reported [21-24]. Therefore, we assumed that the stimulation of Akt phosphorylation by LDR in the kidney of diabetic mice may be one of the possible mechanisms by which LDR prevents the development of diabetic nephropathy [9].

In our previous study, we have demonstrated that diabetes induced a significant increase of renal oxidative damage that was accompanied with renal inflammation and fibrosis, leading to renal dysfunction [9]. We also reported that LDR protection of rat testes from diabetes-induced cell death and oxidative damage was along with an upregulation of testicular superoxide dismutase levels [10]. These two pieces of important information stimulates us to ask whether LDR protect the kidney also through upregulation of antioxidants. Since Nrf2 plays a critical regulation of cellular antioxidant function and LDR was able to upregulate Nrf2 expression in cultured cell line [25], we investigated whether diabetes affects renal Nrf2 expression and whether LDR upregulates Nrf2 expression and function to increase the expression of antioxidants under diabetic conditions. Here we found that diabetes significantly down-regulate renal Nrf2 expression (Figure 4) and function (Figures 5 and 6), which is consistent with other studies indicating the downregulation of $\mathrm{Nrf} 2$ under different pathogenic conditions, including diabetes [26].

We further found that exposure of diabetic mice to either single or accumulated $75 \mathrm{mGy}$ of X-rays can significantly upregulate Nrf2 expression at 3-6h after irradiation. The upregulated Nrf2 function by single or accumulated $75 \mathrm{mGy}$ of X-rays was also reflected by the upregulation of its downstream antioxidants, including NQO1 at 3-6 h and HO-1 at 3-9h (Figures 5 and 6). The difference of peak expression times and durations of these down-stream antioxidants suggests the slight difference of $\mathrm{Nrf} 2$ in regulating these antioxidant components at transcriptional level. Activation of Nrf2 by sulforaphane in vitro and by sulforaphane or MG132 in vivo has been reported to suppress high-level glucose-induced oxidative stress and metabolic dysfunction in human microvascular endothelial cells [27] and reduced diabetic proteinuria in STZ-induced diabetic rats $[28,29]$. In addition, a recent study demonstrated that $\mathrm{Nrf} 2$ can bind to $\mathrm{Bcl}-2$ gene antioxidant response element to upregulate antiapoptotic protein $\mathrm{Bcl}-2$, leading to a prevention of apoptotic cell death [30]. Therefore, upregulation of Nrf2 expression and transcription function may not only turn on antioxidant mechanisms by increasing the expression of antioxidants, but also upregulate antiapoptotic pathways to reduce diabetes-induced renal cell death.

In terms of the hormesis, the optimal and effective doses were extensively documented as $75 \mathrm{mGy}[7,31-34]$. Here we also showed a significantly stimulating effect of $75 \mathrm{mGy} \mathrm{X}$-rays on the stimulation of Akt phosphorylation and the upregulation of $\mathrm{Nrf} 2$ expression and function.
However, accumulated $75 \mathrm{mGy}$ that was given by 3 daily exposures at $25 \mathrm{mGy}$ was similarly effective as single $75 \mathrm{mGy}$ on the stimulation of Akt phosphorylation, but single $25 \mathrm{mGy}$ of X-rays did not have such effect. Our finding is consistent with a recent study that showed that repeated $20 \mathrm{mGy}$ computed tomography scans did not induce genomic instability in reticulocytes, but conferred a significant resistance to larger doses of radiation-induced genomic instability in the bone marrow cells of irradiated mice while exposures to single computed tomography scans exhibit transient genotoxicity, enhanced apoptosis, and enhanced radiation sensitization to subsequent large dose of radiation [35]. This explains why in our previous studies repeated exposure to $25 \mathrm{mGy}$ for 8-12 weeks could significantly prevent diabetes-induced renal and cardiac damage [9]. This is also consistent with the finding by Normura et al., that is, continuous low-dose-rate gamma irradiation ameliorates diabetic nephropathy and increases life span in $\mathrm{db} / \mathrm{db}$ mice through the activation of renal antioxidants [36].

In summary, we have demonstrated that single or accumulated $75 \mathrm{mGy}$ of X-rays can stimulate Akt signaling pathway and upregulate Nrf2 expression and function in diabetic kidneys. Considering that multiple exposure of diabetic mice to $25 \mathrm{mGy} \mathrm{X}$-rays significantly prevented the development of diabetic nephropathy, we assumed here that the stimulated Akt phosphorylation and upregulated Nrf2 expression and function by LDR in the kidney of diabetic mice may be the mechanisms, in part at least, for the prevention by LDR of diabetic nephropathy.

\section{Conflict of Interests}

The authors declare that they have no conflict of interests with SPSS 14.0 software, financial foundation, or any other third party.

\section{Acknowledgments}

This study was supported in part by a Basic Research Award from American Diabetes Association (1-11-BA-17, to L. Cai), a Starting-Up Fund for Chinese-American Research Institute for Diabetic Complications from Wenzhou Medical College (to L. Cai, X. Li and Y. Tan), and Young Scientist Award from National Science Foundation of China (81000294, to C. Zhang).

\section{References}

[1] E. J. Calabrese and L. A. Baldwin, "Radiation hormesis: the demise of a legitimate hypothesis," Human and Experimental Toxicology, vol. 19, no. 1, pp. 76-84, 2000.

[2] G. J. Wang, X. K. Li, K. Sakai, and C. Lu, "Low-dose radiation and its clinical implications: diabetes," Human and Experimental Toxicology, vol. 27, no. 2, pp. 135-142, 2008.

[3] L. Cai, "Research of the adaptive response induced by lowdose radiation: where have we been and where should we go?" Human and Experimental Toxicology, vol. 18, no. 7, pp. 419$425,1999$. 
[4] F. Giacco and M. Brownlee, "Oxidative stress and diabetic complications," Circulation Research, vol. 107, no. 9, pp. 1058 1070, 2010.

[5] W. Wei, Q. Liu, Y. Tan, L. Liu, X. Li, and L. Cai, "Oxidative stress, diabetes, and diabetic complications," Hemoglobin, vol. 33, no. 5, pp. 370-377, 2009.

[6] T. Kuroki, K. Isshiki, and G. L. King, "Oxidative stress: the lead or supporting actor in the pathogenesis of diabetic complications," Journal of the American Society of Nephrology, vol. 14, no. 3, pp. S216-S220, 2003.

[7] W. Y. Guo, G. J. Wang, P. Wang, Q. Chen, Y. Tan, and L. Cai, "Acceleration of diabetic wound healing by low-dose radiation is associated with peripheral mobilization of bone marrow stem cells," Radiation Research, vol. 174, no. 4, pp. 467-479, 2010.

[8] C. Zhang, S. Jin, W. Guo et al., "Attenuation of diabetesinduced cardiac inflammation and pathological remodeling by low-dose radiation," Radiation Research, vol. 175, no. 3, pp. 307-321, 2011.

[9] C. Zhang, Y. Tan, W. Guo et al., "Attenuation of diabetesinduced renal dysfunction by multiple exposures to low-dose radiation is associated with the suppression of systemic and renal inflammation," American Journal of Physiology, vol. 297, no. 6, pp. E1366-E1377, 2009.

[10] H. Zhao, S. Xu, Z. Wang et al., "Repetitive exposures to low-dose X-rays attenuate testicular apoptotic cell death in streptozotocin-induced diabetes rats," Toxicology Letters, vol. 192, no. 3, pp. 356-364, 2010.

[11] O. K. Jin, S. K. Kim, S. E. Hong, T. H. Lee, and C. J. Kim, "Low dose radiation overcomes diabetes-induced suppression of hippocampal neuronal cell proliferation in rats," Journal of Korean Medical Science, vol. 21, no. 3, pp. 500-505, 2006.

[12] M. Heljic and D. P. Brazil, "Protein kinase B/Akt regulation in diabetic kidney disease," Front Biosci Frontiers in Bioscience (Scholar Edition), vol. 3, pp. 98-104, 2011.

[13] X. He, H. Kan, L. Cai, and Q. Ma, "Nrf2 is critical in defense against high glucose-induced oxidative damage in cardiomyocytes," Journal of Molecular and Cellular Cardiology, vol. 46, no. 1, pp. 47-58, 2009.

[14] Y. Zhao, Y. Tan, J. Dai et al., "Exacerbation of diabetes-induced testicular apoptosis by zinc deficiency is most likely associated with oxidative stress, p38 MAPK activation, and p53 activation in mice," Toxicology Letters, vol. 200, no. 1-2, pp. 100-106, 2011.

[15] Y. Tan, T. Ichikawa, J. Li et al., "Diabetic downregulation of Nrf2 activity via ERK contributes to oxidative stress-induced insulin resistance in cardiac cells in vitro and in vivo," Diabetes, vol. 60, no. 2, pp. 625-633, 2011.

[16] K. Yoh, A. Hirayama, K. Ishizaki et al., "Hyperglycemia induces oxidative and nitrosative stress and increases renal functional impairment in Nrf2-deficient mice," Genes to Cells, vol. 13, no. 11, pp. 1159-1170, 2008.

[17] T. Jiang, Z. Huang, Y. Lin, Z. Zhang, D. Fang, and D. D. Zhang, "The protective role of Nrf2 in streptozotocin-induced diabetic nephropathy," Diabetes, vol. 59, no. 4, pp. 850-860, 2010.

[18] U. S. Gaipl, S. Meister, B. Ldermann et al., "Activation-induced cell death and total Akt content of granulocytes show a biphasic course after low-dose radiation," Autoimmunity, vol. 42, no. 4, pp. 340-342, 2009.

[19] C. S. Kim, J. K. Kim, S. Y. Nam et al., "Low-dose radiation stimulates the proliferation of normal human lung fibroblasts via a transient activation of Raf and Akt," Molecules and Cells, vol. 24, no. 3, pp. 424-430, 2007.
[20] M. J. Rane, Y. Song, S. Jin et al., "Interplay between Akt and $\mathrm{p} 38$ MAPK pathways in the regulation of renal tubular cell apoptosis associated with diabetic nephropathy," American Journal of Physiology, vol. 298, no. 1, pp. F49-F61, 2010.

[21] S. Lee, G. Chanoit, R. McIntosh, D. A. Zvara, and Z. Xu, "Molecular mechanism underlying Akt activation in zincinduced cardioprotection," American Journal of Physiology, vol. 297, no. 2, pp. H569-H575, 2009.

[22] H. Z. Zhou, J. S. Karliner, and M. O. Gray, "Moderate alcohol consumption induces sustained cardiac protection by activating PKC- $\varepsilon$ and Akt," American Journal of Physiology, vol. 283, no. 1, pp. H165-H174, 2002.

[23] R. W. Matheny Jr. and M. L. Adamo, "PI3K p110 $\alpha$ and p110 $\beta$ have differential effects on Akt activation and protection against oxidative stress-induced apoptosis in myoblasts," Cell Death and Differentiation, vol. 17, no. 4, pp. 677-688, 2010.

[24] A. Tapodi, B. Debreceni, K. Hanto et al., "Pivotal role of Akt activation in mitochondrial protection and cell survival by poly(ADP-ribose)polymerase-1 inhibition in oxidative stress," The Journal of Biological Chemistry, vol. 280, no. 42, pp. 35767-35775, 2005.

[25] M. Tsukimoto, N. Tamaishi, T. Homma, and S. Kojima, "Lowdose gamma-ray irradiation induces translocation of Nrf2 into nuclear in mouse macrophage RAW264.7 cells," Journal of Radiation Research, vol. 51, no. 3, pp. 349-353, 2010.

[26] P. Palsamy and S. Subramanian, "Resveratrol protects diabetic kidney by attenuating hyperglycemia-mediated oxidative stress and renal inflammatory cytokines via Nrf2-Keap1 signaling," Biochimica et Biophysica Acta, vol. 1812, no. 7, pp. 719-731, 2011.

[27] M. Xue, Q. Qian, A. Adaikalakoteswari, N. Rabbani, R. BabaeiJadidi, and P. J. Thornalley, "Activation of NF-E2-related factor-2 reverses biochemical dysfunction of endothelial cells induced by hyperglycemia linked to vascular disease," Diabetes, vol. 57, no. 10, pp. 2809-2817, 2008.

[28] Z. F. Luo, W. Qi, B. Feng et al., "Prevention of diabetic nephropathy in rats through enhanced renal antioxidative capacity by inhibition of the proteasome," Life Sciences, vol. 88, no. 11-12, pp. 512-520, 2011.

[29] H. Zheng, S. A. Whitman, W. Wu, G. T. Wondrak, P. K. Wong et al., "Therapeutic potential of Nrf2 activators in streptozotocin-induced diabetic nephropathy," Diabetes, vol. 60, no. 11, pp. 3055-3066, 2011.

[30] S. K. Niture and A. K. Jaiswal, "Nrf2 protein up-regulates antiapoptotic protein Bcl-2 and prevents cellular apoptosis," The Journal of Biological Chemistry, vol. 287, no. 13, pp. 98739886, 2012.

[31] S. Z. Liu, X. Su, Z. B. Han, Y. C. Zhang, and J. Qi, "Effect of low dose radiation on intracellular calcium and protein kinase $\mathrm{C}$ in lymphocytes," Biomedical and Environmental Sciences, vol. 7, no. 3, pp. 284-291, 1994.

[32] S. Z. Liu, SuXu, Y. C. Zhang, and Y. Zhao, "Signal transduction in lymphocytes after low dose radiation," Chinese Medical Journal, vol. 107, no. 6, pp. 431-436, 1994.

[33] S. L. Chen, L. Cai, Q. Y. Meng, S. Xu, H. Wan, and S. Z. Liu, "Low-dose whole-body irradiation (LD-WBI) changes protein expression of mouse thymocytes: effect of a LD-WBIenhanced protein RIP10 on cell proliferation and spontaneous or radiation-induced thymocyte apoptosis," Toxicological Sciences, vol. 55, no. 1, pp. 97-106, 2000.

[34] X. Liang, Y. H. So, J. Cui et al., "The low-dose ionizing radiation stimulates cell proliferation via activation of the MAPK/ERK pathway in rat culturedmesenchymal stem cells," Journal of Radiation Research, vol. 52, no. 3, pp. 380-386, 2011. 
[35] N. Phan, M. de Lisio, G. Parise, and D. R. Boreham, "Biological effects and adaptive response from single and repeated computed tomography scans in reticulocytes and bone marrow of C57BL/6 mice," Radiation Research, vol. 177, no. 2, pp. 164-175, 2012.

[36] T. Nomura, X. H. Li, H. Ogata, K. Sakai, T. Kondo et al., "Suppressive effects of continuous low-dose-rate gamma irradiation on diabetic nephropathy in type II diabetes mellitus model mice," Radiation Research, vol. 176, no. 3, pp. 356-365, 2011. 


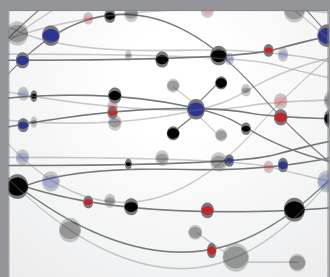

The Scientific World Journal
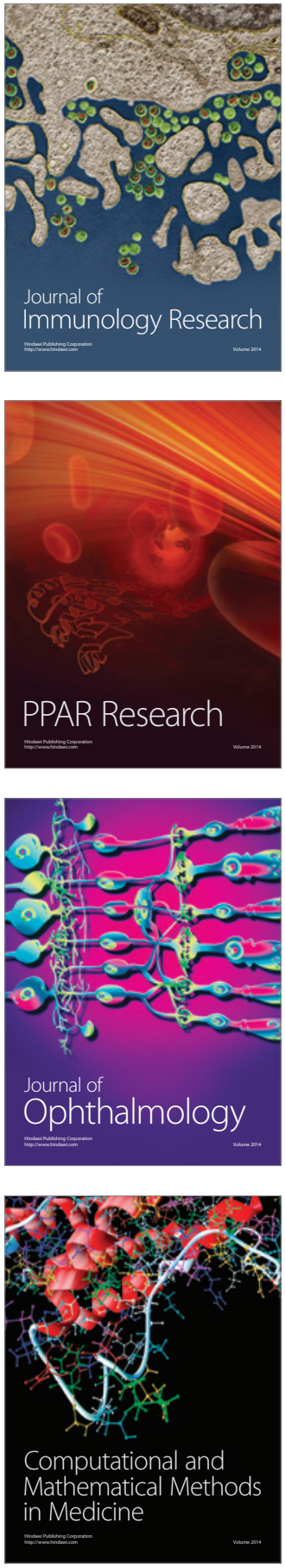

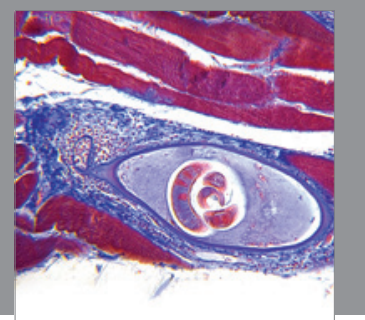

Gastroenterology

Research and Practice
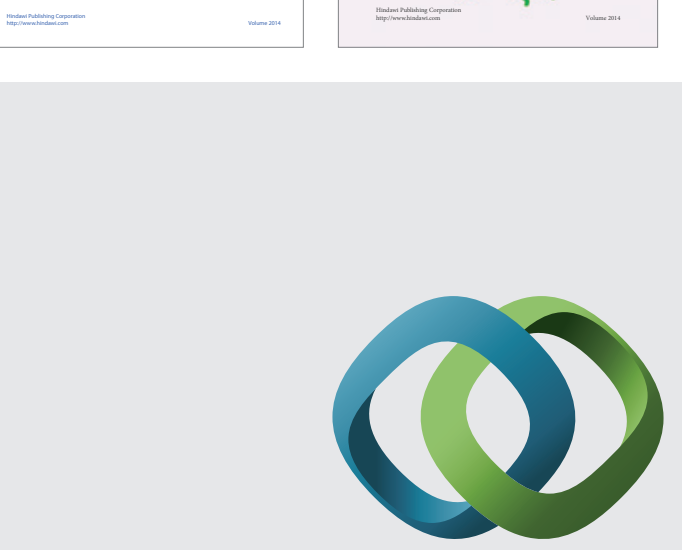

\section{Hindawi}

Submit your manuscripts at

http://www.hindawi.com
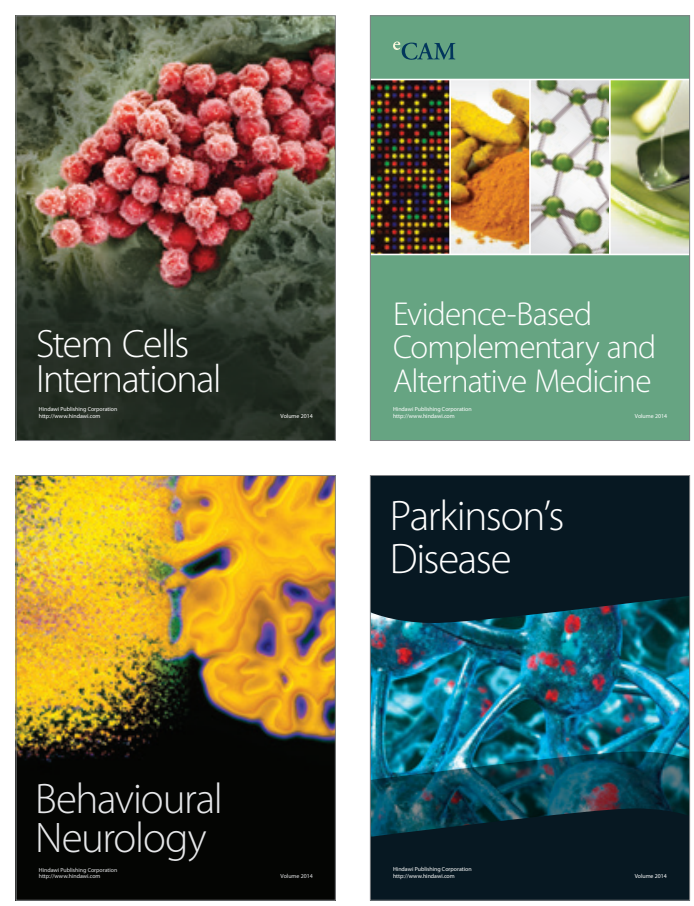

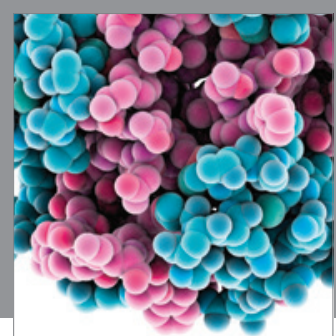

Journal of
Diabetes Research

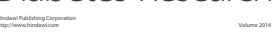

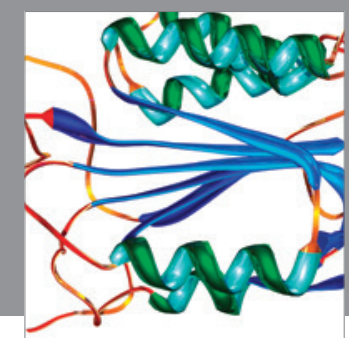

Disease Markers
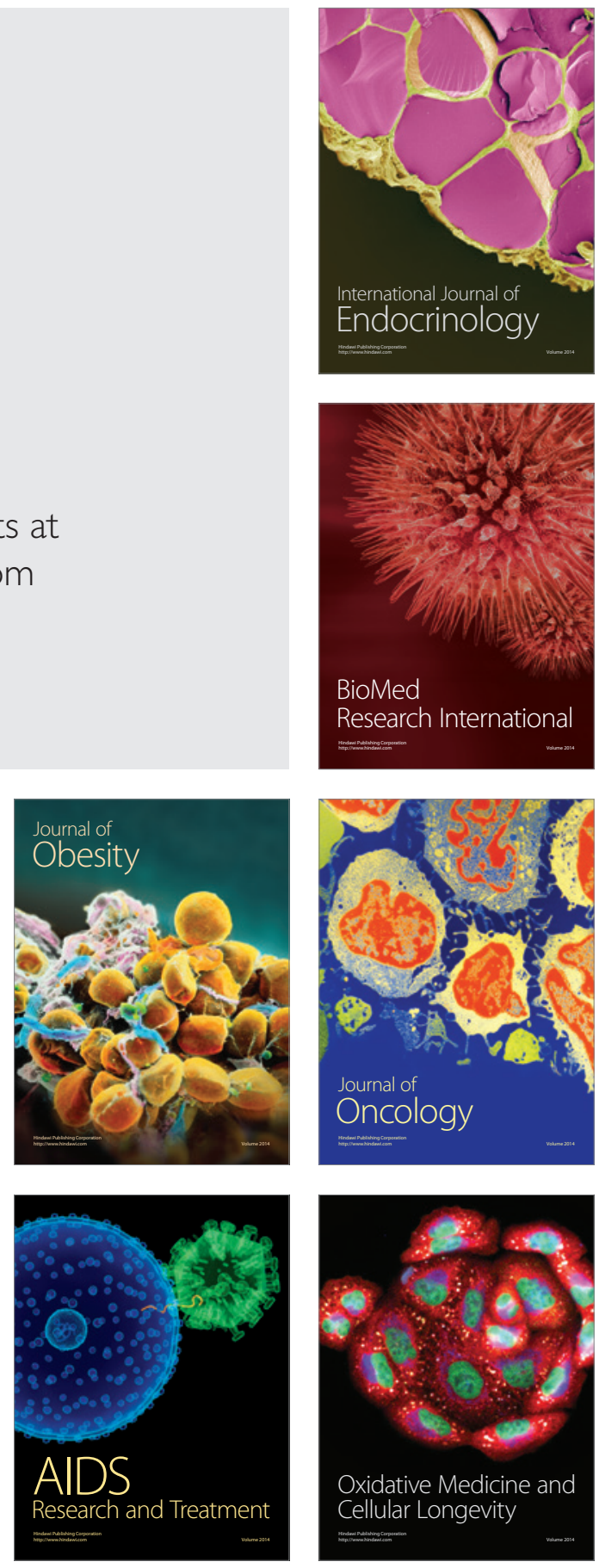